\title{
РОЗДІЛ 5. ДОШКІЛЬНА ПЕДАГОГІКА
}

\section{УСНА НАРОДНА ТВОРЧІСТЬ ЯК ЗАСІБ ФОРМУВАННЯ МОРАЛЬНОЇ ГОТОВНОСТІ СТАРШИХ ДОШКІЛЬНИКІВ ДО НАВЧАННЯ В НОВІЙ УКРАЇНСЬКІЙ ШКОЛІ}

\author{
ORAL FOLK ART AS A MEANS OF FORMING THE MORAL \\ READYNESS OF SENIOR PRESCHOOL TEACHERS TO STUDY \\ IN THE NEW UKRAINIAN SCHOOL
}

У статті проведено теоретичний аналіз психолого-педагогічної літератури із проблеми формування моральної готовності старших дошкільників до навчання в Новій українській школі засобами народної творчості. Закцентовано увагу на народній творчості як важливому засобі фрормування особистості дитини, їі моральних якостей, розвитку пам'яті, мовлення, уваги, мислення. Розкрито сутність понять «готовність до шкільного навчання», «моральне виховання».

Народна творчість - важлива частина національної культури. Вона $є$ джерелом пізнання історії народу, його суспільної свідомості, етичних норм та естетичних уявлень.

Для виховання дітей дошкільного віку фолььклор не втрачає свого виховного впливу. Саме в дошкільному віці відбувається найбільш інтенсивний розвиток особистості. У чей період починають розвиватися ті почуття, риси характеру, які незримо пов'язують дитину зі своїм народом. Коріння зв'язку - у мові народу, його піснях, музиці, іграх, у враженнях, одержуваних маленькою людиною від природи рідного краю, у деталях побуту, вдачі та звичаях людей, серед яких вона живе.

Народна творчість - че одна з основ мовного, морального, естетичного, патріотичного виховання. Створений століттями поетичний матеріал малих фольклорних фрорм у поєднанні з реальністю, перебуваючи в буденному стані, поступово перетворює ії, $і$ в результаті поетизація звичайних предметів і явищ підкреслює їхню достовірність $і$ водночас підносить буденне, збагачує розвиток дитини.

Процеси перебудови в сучасній школі, утвердження нової гуманістичної парадигми освіти ведуть до посилення культурологічної спрямованості, переорієнтації на формування духовності, ціннісних орієнтацій особистості, її творчий розвиток. Реалізація культурно-творчої фрункції освіти передбачає цілеспрямоване використання надбань національної культури в навчанні та вихованні молодого покоління, а також у профресійній підготовці вчителя до цієї діяльності.

DOI https://doi.org/10.32843/2663-

6085/2021/34-1.29

Тесленко С.О.,

викладач кафедри дошкільної освіти

Миколаївського національного

університету імені В.О. Сухомлинського
Ключові слова: усна народна творчість, моральна готовність, старші дошкільники, заклад дошкільної освіти, Нова українська школа.

This article provides a theoretical analysis of psychological and pedagogical literature on the problems of shaping the moral readiness of older preschoolers to learning in the New Ukrainian school by means of folk art. Focused on folk art as an important means of shaping children's personality, their moral qualities, the development of memory, language, respect, thinking. The essence of the concept of "readiness for school education", "moral education". Folk art is an important part of national culture. It is the source of knowledge of the history of the people, their social conscience, ethical norms and natural concepts.

Folklore does not lose its educational impact on pre-school children. It is in the pre-school age that the most intense development of personality takes place. This period begins to develop those feelings, character risks, which invisibly connect the child to their own people. The root of the link - in the language of the people, their songs, music, games, the impressions received by a small person from the nature of the native land, the details of life, the challenge and the customs of the people, among whom she lives. Folk art - one of the foundations of literary, moral, natural, patriotic education. Created by the centuries of poetic material small folk forms in combination with reality, being in a mundane state, gradually transforming it, and as a result of the poetization of everyday objects and phenomena to confirm their veracity and at the same time presents mundane, enriching the development of the child.

The processes of change in modern schools, the establishment of a new humanistic paradigm of education lead to an increase in cultural orientation, re-orientation on the formation of spirituality, value orientations of the individual, its creative development. Realization of cultural and creative function of education requires purposeful use of national culture in the teaching and education of the younger generation, as well as in the professional preparation of the teacher for this activity.

Taking into account the requirements of the New Ukrainian School, today's first grade student must be morally prepared for school. This is one of the key tasks of preschool institutions. Key words: authentic folk art, moral readiness, older preschool children, preschool education institutions, New Ukrainian School. 
Постановка проблеми в загальному вигляді. Нині назріла потреба для педагогів дошкільної освіти і батьків дітей дошкільного віку глибоко вивчати українську етнопедагогіку, відновити народне виховання дітей із метою збереження нації, забезпечення духовної єдності поколінь. Не випадково в народі кажуть: «Якщо твої плани розраховані на рік - сій жито, якщо на десятиліття саджай дерева, якщо твої плани розраховані на віки - виховуй дітей».

Моральне виховання старших дошкільників нині є складовою частиною змісту роботи закладів дошкільної освіти і сім'ї, головним завданням яких $€$ насамперед фрормування моральної свідомості та моральної готовності до навчання в Новій українській школі. Вагоме місце в цьому процесі належить українській народній творчості, яка становить собою невичерпне джерело людської мудрості щодо виховання молодого покоління.

Основні вимоги до морального виховання дітей висвітлено в законах України «Про освіту» (2017 р.), «Про дошкільну освіту» (2020 р.), «Про охорону дитинства», у Базовому компоненті дошкільної освіти в Україні (2012р.), Концепції громадянського виховання особистості в умовах розвитку української державності й інших нормативних документах, які визначили провідні напрями морально-духовного вдосконалення особистості.

Аналіз останніх досліджень і публікацій. Аналіз праць учених засвідчив, що досліджено такі питання морального виховання, як: психологічні механізми становлення й розвитку моральних почуттів, уявлень, суджень, переконань і поведінки (К. Абульханова-Славська, С. Анісімов, Л. Божович, Д. Ельконін, О. Запорожець); специфріка й закономірності морального розвитку дошкільника (Ю. Аркін, Р. Ібрагімова, Є. Субботський, С. Якобсон); моральна свідомість (Л. Артемова, І. Бех, Л. Божович, Р. Буре, Л. Виготський, В. Зеньковський, В. Нечаєва, Ж. Піаже, С. Рубінштейн та інші). Одним із провідних засобів морального виховання та фрормування моральної свідомості дітей дошкільного віку як класики вітчизняної педагогіки (С. Русова, М. Стельмахович, В. Сухомлинський та інші), так і сучасні вчені (А. Богуш, В. Бойко, О. Губко, Л. Кіліченко, В. Кононенко, Г. Кошелєва, В. Кузь) уважають український фрольклор. Усну народну творчість здавна широко використовували в народній педагогіці як засіб фрормування в дітей моральних норм і оцінок із позицій добра, справедливості, розуміння ними вчинків та поведінки дорослих як основи моральної свідомості.

Виділення не вирішених раніше частин загальної проблеми. Актуальність теми зумовлена необхідністю вирішення проблеми фрормування моральної готовності дітей старших дошкільників до навчання в Новій українській школі за допомогою усної народної творчості у складних та неоднозначних умовах соціуму. У цей час спостерігається зниження інтересу до народної творчості загалом і в дитячому середовищі зокрема, що, у свою чергу, ускладнює прилучення дітей до світу народності, а через неї - до фрундаментальних цінностей моралі.

Мета статті - теоретичне обґрунтування доцільності використання усної народної творчості як засобу фрормування моральної готовності старших дошкільників до навчання в Новій українській школі

Виклад основного матеріалу. Робота з виховання дитини - процес послідовний і систематичний. Важливо, щоб діти, постійно отримуючи моральні знання й уявлення, опинялися в життєвих ситуаціях, які б сприяли емоційному переживанню отриманих знань, їх усвідомленню й закріпленню, щоб змінити на краще моральність нашого суспільства, необхідно пам'ятати, що вихованість дітей дошкільного віку - результат кропіткої щоденної роботи педагогів і батьків на всіх етапах навчання, виховання і розвиту особистості, а також тих реальних міжлюдських стосунків, у які включається дитина $з$ перших днів свого життя й активним учасником яких вона залишається всі наступні роки свого життя.

Сучасна педагогіка базується на відродженні духовності українського народу, його менталітету. Тому дошкільне виховання має ґрунтуватися на засадах родинного виховання, надбаннях народної педагогіки, народної творчості, фольклору.

Усна народна творчість узагальнює багатовіковий людський досвід, вона є носієм і втіленням народної мудрості, народного світогляду, його ідеалів. У ній відбиваються національна психологія, національна свідомість народу, це його історія, фрілософрія, мораль, правові закони. Узагальнені фрорми життя, виховання, навчання, спостережливості втілювались у рідному слові, закріплювались, передавались із вуст в уста, шліфувались, набували значущості «народних перлин», які передавались як найдорожча спадщина.

Усна народна творчість - важлива частина національної культури. Вона $є$ джерелом пізнання історії народу, його суспільної свідомості, етичних норм та естетичних уявлень. Фольклор здійснив відчутний вплив на становлення й розвиток літератури. Народнопоетичні мотиви відіграли помітну роль у формуванні літературних сюжетів, а фрольклорні теми, образи, персонажі використовувалися й переосмислювалися літературою упродовж усього її існування.

Формування морального виховання в закладах дошкільної освіти здійснюється на засадах народних традицій та обрядів не тільки в освітньо-виховній роботі, але й у повсякденному житті; у цьому допомагає використання українських народних свят, бесід, прогулянок, екскурсій, які прищеплю- 
ють старшим дошкільникам любов до українських народних традицій.

Дослідження проблеми моральної готовності дітей старшого дошкільного віку до навчання в Новій українській школі засобами усної народної творчості зумовило насамперед визначити сутність понять «готовність до школи», «моральна готовність», «народна творчість».

У психологічному словнику поняття «готовність до шкільного навчання» розглядається як сукупність морфоорізіологічних особливостей дитини старшого дошкільного віку, яка забезпечує успішний перехід до систематичного, організованого шкільного навчання [7].

Готовність до шкільного навчання - це бажання й усвідомлення необхідності вчитися, що виникає в результаті соціального дозрівання дитини, появи в неї внутрішніх суперечностій, які визначають мотивацію до навчальної діяльності [8, с. 128].

Найповніше поняття «готовність до школи» визначив Л. Венгер. Він уважав, що готовність до школи - це певний набір знань і вмінь, у якому повинні існувати всі інші елементи, хоча рівень їхнього розвитку може бути різний [6].

Моральне виховання - виховна діяльність школи і сім'ї, що має на меті формування стійких моральних якостей, потреб, почуттів, навичок і звичок поведінки на основі засвоєння ідеалів, норм і принципів моралі, участь у практичній діяльності [2].

Як зазначив В. Сухомлинський, народна педагогіка «знає, що дитині посильне, і що непосильне», бо в ній органічно «поєднується життєва мудрість 3 материнською і батьківською любов'ю». Вона «не боїться, що праця втомлює, вона знає, що праця неможлива без поту і мозолів». У ній стверджується і те, що праця, вимагаючи від людини великого старання, сили, відповідальності, $€$ не тільки важкою, а й радісною [9].

Під час реалізації науково-дослідної теми кафедри «Теоретико-методичні засади фрормування готовності дітей старшого дошкільного віку до навчання в Новій українській школі» було впроваджено в заклади дошкільної освіти методику формування моральної готовності дітей старшого дошкільного віку засобами усної народної творчості до навчання в Новій українській школі. Головним у поставленому завданні для педагогів і науковців стало, щоб освітньо-виховний процес був цікавим, змістовним, насиченим пошуком творчих, альтернативних шляхів розвитку потенціальних можливостей кожної дитини, ураховуючи особисті якості дитини та життєвий досвід. Так, під час педагогічної практики студенти спеціальності 012 «Дошкільна освіта» на заняттях, в іграх і повсякденній роботі на екскурсіях, у побуті формували основи моральності та культури, світогляду дитини у процесі засвоєння основ усної народної творчості.
Погоджуємось із думкою Н. Гавриш, що у традиційній практиці дошкільної освіти в роботі з літературними текстами використовуються переважно застарілі підходи, за яких ігнорується значення практично-чуттєвого досвіду як ефективного механізму засвоєння дитиною літературного тексту, визначення значущих для себе смислів. Саме тому робота була організована таким чином, щоб усна народна творчість стала надбанням дитячого розуму й душі. На наш погляд, цього можна досягти дотриманням принципу організації активної пізнавальної діяльності дітей у різних видах діяльності під час реалізації технології літературного проєкту.

Н. Гавриш наголошує, що підґрунтям технології літературного проєкту є теоретичні положення психолого-педагогічних досліджень про особливості художньо-естетичного сприймання і привласнення дошкільниками змісту й ідей художнього твору, смислоутворення, відкриття читачем власних смислів у прочитаному [1, с. 19].

Під час упровадження методики орормування моральної готовності дітей старшого дошкільного віку ми керувалися алгоритмом конструювання літературного проєкту, а саме: складання інтелектуальної карти; підбір фрорм і методів реалізації змісту проєктів на різних його етапах, розроблення творчих завдань і вправ за змістом твору та дидактичного матеріалу

За основу роботи першого напряму взято українську народну казку, яка синтезує знання, що подаються дітям. До казки ми звернулися не випадково, адже казка для дитини - це не просто вигадка, франтазія, це - особлива реальність, реальність її почуттів. До початку роботи за інтегрованою системою змісту дошкільної освіти педагоги і науковці ретельно передивились та проаналізували програмові казки і відібрали ті, зміст яких мав допомогти, на нашу думку, розкрити дітям зв'язки між явищами, стосунки між людьми тощо; із чим і треба було ознайомлювати вихованців. Сам процес планування освітнього процесу - це завжди творчість. У плані відтворюється робота над казкою в різних видах діяльності дітей протягом тривалого часу. Роботу над казкою планувалось завершувати театралізованим дійством. Це може бути вистава: інсценування, драматизація або розвага з елементами театралізованої діяльності з використанням різних видів театру.

Другий напрям реалізувався через подання знань про окремі сфери життєдіяльності людини, як-от: природа, культура, суспільство, наука і техніка, всесвіту. Основною фрормою були тематичні заняття (завдання - підвищити розумову активність дитини). Цьому допомагають прийоми порівняння, питання, індивідуальні завдання, тому неодноразове звернення до тієї самої теми лише сприяє розвитку в дітей уваги і тривалого 
збереження зацікавленості до поданої теми, було об'єднано в одну тему заняття не тільки з рідної мови, а й з ознайомлення із природою, музикою, зображувальною діяльністю. Важливим був також тісний взаємозв'язок із батьками.

Сутність експериментальної роботи полягала в тому, що подання знань дітям та їх застосування у практичній діяльності здійснювалися шляхом інтеграції (об'єднання) усіх ланок розвивального навчання та виховання. Наведемо приклади такої роботи:
Висновки. Ми переконалися в тому, що моральний зміст легше засвоюється дітьми, якщо він пропонується казковими героями. Результативність моральної готовності старших дошкільників до навчання в Новій українській школі засобами народної творчості значною мірою залежить від актуалізації ії змісту та використання 3 урахуванням вікових особливостей дітей, педагогічних умов діяльності закладу дошкільної освіти, особистості педагога дошкільного закладу і його творчого потенціалу.

\begin{tabular}{|c|c|c|}
\hline Моральна якість & Літературний твір & Види роботи \\
\hline Відповідальність & «Котик і Півник» & $\begin{array}{l}\text { Інтегроване заняття «Що таке відповідальність». } \\
\text { Полілоги «Відповідальна людина, яка вона?», «Кого в нас у } \\
\text { групі можна назвати відповідальним?». } \\
\text { Гра: «Можу, хочу, потрібно», «Намалюй свій режим дня». }\end{array}$ \\
\hline Працьовитість & «Колосок» & $\begin{array}{l}\text { Інтегроване заняття «Як досягти своєї мети?». } \\
\text { Полілоги «Чим небезпечні лінощі?», «Хто з казкових героїв } \\
\text { завдяки працьовитості досяг успіху?», «Хто такі майстри?». } \\
\text { Аплікація «Країна майстрів». }\end{array}$ \\
\hline Чесність & «Лисичка зі скалочкою» & $\begin{array}{l}\text { Інтегроване заняття «Чесність - запорука успішності». } \\
\text { Полілог «Чи легко бути чесним?». } \\
\text { Гра «Підбери прислів'я до казкового героя». Намалюй кра- } \\
\text { їну чесності. Які казкові герої там будуть мешкати? }\end{array}$ \\
\hline Повага, довіра & $\begin{array}{l}\text { «Дві кізочки» М. Коцю- } \\
\text { бинського, «Два цапки» }\end{array}$ & $\begin{array}{l}\text { Інтегровані заняття «Повага до інших, повага до себе», } \\
\text { Полілоги «Що означає прислів'я «Довіряй, але переві- } \\
\text { ряй»?», «Які вчинки казкових героїв викликають повагу?». } \\
\text { Створення колажу «я відповідаю». }\end{array}$ \\
\hline Співчуття & «Кривенька качечка» & $\begin{array}{l}\text { Інтегровані заняття: «Доброта», «Особливі люди». Полілоги } \\
\text { «Чим вимірюється доброта?», «Хто із казкових героїв вміє } \\
\text { співчувати?». Гра «Оціни вчинок», «Добре-погано». } \\
\text { Виготовлення книги добрих справ. }\end{array}$ \\
\hline
\end{tabular}

\section{БІБЛІОГРАФІЧНИЙ СПИСОК:}

1. Гавриш Н. Технологія літературного проекту: як допомогти дитині відкрити важливі смисли за допомогою художнього твору. Мистецтво та освіта : науково-методичний журнал. 2018. № 3 (89). C. 19-25.

2. Духовно-моральне виховання дітей дошкільного віку засобами музейної педагогіки, музичного та художньо-прикладного мистецтва : тематичний збірник праць / упорядн. : А. Волосюк ; за заг. ред. Л. Шишолік. Рівне : РОІППО, 2014. $50 \mathrm{c}$.

3. Лисенко Н. Етнопедагогіка дитинства : навчально-методичний посібник. Київ : Видавничий дім «Слово», 2011. 720 с.
4. Максимюк С. Педагогіка : навчальний посібник. Київ : Кондор, 2005. 667 с.

5. Михальчук О. Теоретичні аспекти морального виховання особистості дитини дошкільного віку. Вісник Черкаського університету. 2018. № № 10-11. C. 59-65.

6. Павелків Р. Вікова психологія. 2-е вид. Київ : Кондор, 2015. 469 c.

7. Психологічний словник / за ред. В. Войтка. Київ : Вища школа, 1982. 214 с.

8. Словник української мови : в 11-ти т. / Інститут мовознавства АН УРСР ; за ред. І. Білодіда. Київ : Наукова думка, 1970-1980. С. 128.

9. Сухомлинський В. Батьківська педагогіка. Київ : Рад. школа, 1978. 283 с. 